\title{
COMPETITION LAW IN MALAYSIA
}

\author{
Safinaz Mohd Hussein \\ Law Faculty, Universiti Kebangsaan Malaysia \\ Email : finaz@ukm.my
}

\begin{abstract}
Abstrak
Meningkatnya kesadaran akan pentingnya persaingan usaha menimbulkan munculnya regulasi tertentu di tingkat nasional dan hal inilah yang terjadi di Malaysia, yakni dengan berlakunya Undang-Undang Persaingan Usaha Malaysia 2010. Disahkannya hukum persaingan umum seperti Undang-Undang Persaingan Usaha Malaysia 2010 pasti akan berdampak pada undang-undang sektoral seperti ketentuan dalam Peraturan Ekonomi CMA 1998. Biasanya hukum persaingan usaha memang di atas undangundang sektoral, kecuali jika terdapat pengecualian yang diberikan terhadap hukum tersebut, sehingga harus dikembangkan untuk beberapa waktu dan mengikuti kecenderungan pengembangan hukum yang mendukung. Oleh karena itu, integrasi bagian tertentu dari undang-undang sektoral ke dalam hukum persaingan umum harus dibuat.
\end{abstract}

Kata kunci : hukum persaingan usaha, aturan ekonomi

\section{Abstract}

The increasing awareness of the importance of competition brings about the introduction for such a regulation at the national level and this is witnessed by the enactment of the Malaysian Competition Act 2010. The passing of a general competition law like the Competition Act 2010 will definitely have an impact on sectoral laws like the provisions in the Economic Regulation of the CMA 1998. Normally general competition law prevail over sector-specific law that regulates competition unless exemption to such laws is done which even if given, will have to be lifted at some time and the trend in the development in this area of law also supports this. Therefore, the integration of sector-specific competition laws into the general competition law will have to be made.

\section{Key words : competition law, economic regulation}

\section{Acknowledgment}

Regulatory reforms in Malaysia took place as a result of privatization ${ }^{1}$ in the 80 s. Privatization refers to the transfer of assets and services from the public sector to the private sector reducing the role of the government. The process of privatization includes deregulation and opening up state monopolies to greater competition. In the absence of a national competition law or policy, sectoral approach to competition regulation was adopted.

The New Economic Policy (NEP) is one of the most central forms of development policy made by the government during the post-independence era. It aims to eradicate poverty as well as equalizing the economic imbalance between major races in the country. Soon after, the government's privatization policy started in the mid $80 \mathrm{~s}$. As a result of this, regulation on ownership was put in place through control over entry conditions such as licensing ${ }^{2}$. Competition regulation seeks to prevent the development of market concentration that might threaten the competitive functioning of markets. Economic regulation, on the other hand, restricts firms' decisions over prices, quantity

1 Khairiah Salwa Mokhtar, Privatisation Malaysia Airlines, Penerbit UKM, 2008, p. 78-79.

2 For example, licences to operate are required in certain industries like the banking sector where licenses are approved by the Minister of Finance and issued by the Bank Negara. Similar situation can be seen in the communications industry (CMA 1998) and the aviation industry (Civil Aviation Act 1969) where service providers are required to have licenses to operate. 
and entry-exit decisions in cases where the presence of market power is inevitable (i.e. natural monopolies $^{3}$ due to scale economies). ${ }^{4}$ However, economic regulation sometimes has impacts on competition. (E.g. relaxation in entry conditions can reduce concentration in a market). ${ }^{5}$ In Malaysia, economic regulation is more common than competition regulation. Examples of economic regulation in Malaysia are price control regulations ${ }^{6}$, entry-exit condition (for example via licensing), ${ }^{7}$ mergers and acquisitions ${ }^{8}$, and trade and industrial policies 9 . Examples of the various statutes that regulate commercial and trading activities are the Price Control Act 1946, the Trade Description Act 1972, the Hire-Purchase Act 1967, the Control of Supplies Act 1961, the Weight and Measures Act 1972, the Consumer Protection Act 1999 and the Direct Sales Act 1993. These statutes regulate competition by protecting the rights of the consumers and preventing various acts, which are considered illegal on the part of the provider or traders. These laws address specific issues for example the control of price and the control of supplies. It does not address competition issues such as market structures and power like anti-competitive practices and the abuse of dominant position. However, these sectoral laws could not be equated to sector-specific competition laws as it only addresses specific issues like the Price Control Act 1946 tackles the issue of control of price whereas sector-specific laws would not only cover pricing issues but of wider scope which includes anti-competitive behavior and abuse of market power. This scenario pictures the existence of economic regulation through the years since the implementation of the NEP and the government's privatization policy. At present, two sectors expressly addresses competition in Malaysia i.e. the communications and multimedia and the energy sectors through the Communications and Multimedia Act $1998^{10}$ and the Energy Commission Act 200111 respectively.

Malaysia's interest in implementing competition law in the country was stated in the Eighth Malaysia Plan in Paragraph 16.32, which stated:

During the Plan period (2001-2005), efforts will be made to foster fair trade practices that will contribute towards greater efficiency and competitiveness of the economy. In this context, a fair trade policy and law will be formulated to prevent anti-competitive behaviour such as collusion, cartel price fixing, market allocation and the abuse of market power. The fair trade policy will, among others, prevent firms from protecting or expanding their market shares by means other than greater efficiency in producing what consumer's want.

Hence, the Ministry of Domestic Trade and Consumer Affairs (at that time) was given the mandate to formulate a general competition law. Other than commitments and pressures from international bodies, the rationale for the Malaysian competition law are trade liberalization, privatization, the prevention of incidences of anti-competitive practices in the market and the realization for the need of a level playing field. ${ }^{12}$ Initially it was stated that the Malaysian competi-

3 William Baumol's definition of "natural monopoly" is "an industry in which multiform production is more costly than production by a monopoly", Baumol, W, "The Proper cost Tests or Natural Monopoly in a Multiproduct Industry", American Economic Review 67, 1977, p. 810. This usually occur in utilities for example where the costs of having one more provider is costly because the infrastructure required to do so is costly and immense.

4 Lee, C, "The Institutional Policy Framework For Regulation And Competition In Malaysia", Centre on Regulation and Competition Working Paper Series, Institute for Development Policy and Management, University of Manchester, December 2002, citing Vascusi, W, Kip, Vernon, J.M, Joseph, E, Harrington, Jr., Economies of Regulation and Antitrust, Third Edition, Cambridge, MIT Press, 2000 , p. 3.

5 Ibid., p. 5.

6 For example the Price Control Act 1946, and Supply Control Act 1961.

7 The Communications and Multimedia Act 1998 and the banking sector where licences are approved by the Minister of Finance and issued by the central bank (Bank Negara).

8 For example the Securities Commission Act 1993 and the Malaysian Code on Take-Overs and Mergers 1998.

9 The policy that affects the automative industry.

10 The Communications and Multimedia Act 1998 on the other hand, has a specific chapter in the act that deals with competition practices. Competition regulation in the act lists down three clear prohibitions namely:

i. Prohibition on anti-competitive conduct (section 133);

ii. Prohibition on entering into collusive agreements (section 135); and

iii. Prohibition on tying or linking arrangements (section 136).

11 Section 14 provides that the Commission shall have the function to 'promote and safeguard competition and fair and efficient market conduct or, in the absence of a competitive market, to prevent the misuse of monopoly or market power in respect of the generation, production, transmission, distribution and supply of electricity and the supply gas through pipelines.'

12 Shila Dorai Raj, “The Need to Have a Competition Law in Malaysia” Half-Day Seminar on Competition Law \& Policy: Future \& Prospect in Malaysia, 6 November 2008, Faculty of Law, IIUM. 
tion law was to be known as the Malaysian Fair Trade Practice Act (FTPL) and its objectives are to promote economic development and protect the interest of consumers by promoting and protecting the process of competition. ${ }^{13}$

\section{Analize}

\section{a. Competition Act 2010}

In 2010 the Malaysian Parliament finally passed the Competition Act 2010. The Competition Act 2010 is divided into six parts. However, only Part II deals with anti-competitive practices. The other parts contain provisions on procedures of the Competition Commission (also known as the Malaysian Competition Commission or MyCC - established by the Competition Commission Act 2010), provisions on the competition appeal tribunal and general and preliminary provisions. Part II of the Competition Act 2010 contains four chapters. It contains chapters on anti-competitive agreement ${ }^{14}$, abuse of dominant position ${ }^{15}$, market review ${ }^{16}$ and a chapter on exclusion ${ }^{17}$. Generally, most competition law deals with three general aspects of regulation, i.e. prohibitions on anti-competitive conduct, abuse of dominant position and rules on mergers and acquisitions. Two of these elements are seen adopted by the Competition Act 2010. The Competition Act 2010 addresses both anti-competitive conduct and abuse of dominant position in Chapters 1 and 2 of Part II. It does not however contain provisions on mergers and acquisition, taking into account the views of various parties like the Securities Commission and the Bank Negara Malaysia that they are already addressed under the Securities Commission Act $1993^{18}$ and the Malaysian Code on Take-overs and Mergers 1998. ${ }^{19}$ This argument can be criticized especially when both instruments lack concrete competition provisions.

The Competition Act 2010 contains two main prohibitions i.e. prohibition on anti-competitive agreement ${ }^{20}$ and the prohibition on the abuse of dominant position ${ }^{21}$. Section 4 of the Competition Act 2010 prohibits, "a vertical or horizontal agreement between enterprises ... which has the object or effect of significantly preventing, restricting or distorting competition in any market ..." Subsection (2) of the same section further lists a number of horizontal agreements which are per se prohibited. They are:

(a) price fixing;

(b) sharing of market or sources of supply;

(c) limit or control of production, market outlets or access, technical or technological development, investment;

(d) bid rigging. ${ }^{22}$

The second general prohibition addresses the abuse of dominant position. Section 10(1) of the Competition Act 2010 provides that "an enterprise is prohibited from engaging, whether independently or collectively, in any conduct which amounts to an abuse of a dominant position in any market for goods..." and an abuse of a dominant position may include-

(a) the imposition of unfair purchase or selling price whether directly or indirectly or unfair trading condition;

(b) the act of limiting or controlling the production, market outlets or market access, technical or technological development, or investment;

(c) refusing to supply;

(d) the application of dissimilar conditions to equivalent transactions with trading partners;

(e) tying;

(f) predatory behaviors;

(g) buying up scarce supply of goods or resources without a reasonable commercial justification. ${ }^{23}$

The Act also provides that the market share of an enterprise is not by itself an indication of dominance. ${ }^{24}$ The rest of the provisions under Part II of the Competition Act 2010 contain provi-

\footnotetext{
13 Ibid.

14 Sections 4 to 9 Competition Act 2010.

15 Section 10 Competition Act 2010.

16 Sections 11 and 12 Competition Act 2010.

17 Section 13 Competition Act 2010.

18 Section 33A of the Securities Commission Act 1993 provides for a prescription of a code on take-overs and mergers.

19 Parliamentary Debate, 8 April 2010.

20 Section 4, Competition Act 2010 (Act 713).

21 Section 10, Competition Act 2010 (Act 713).

22 Section 4(2), Competition Act 2010 (Act 713).

23 Section 10(2), Competition Act 2010 (Act 713).

24 Section 10(4), Competition Act 2010 (Act 713).
} 
sions on market review to study the structure of the market and conduct of the players and exclusion provisions where activities or conducts listed in the Second Schedule will be excluded from provisions of Part II (Anti-competitive practices). In other words, the Competition Act 2010 encompasses lists of anti-competitive conducts, which are prohibited $^{25}$, approaches to counter anti-competitive conduct and list of exemptions ${ }^{26}$ and authorizations. Two types of approaches will be adopted to counter anti-competitive conduct, preventive ${ }^{27}$ approach and the remedial ${ }^{28}$ approach. These approaches will be structural ${ }^{29}$ and behavioral in nature $^{30}$. These approaches are similar to those in other jurisdictions. As mentioned by UNCTAD, there is no unique model to follow, however, the Competition Act 2010 contains characteristics generally similar to those proposed by the model law.

\section{b. Regulating Competition In The Malaysian Communications And Multimedia Industry}

\section{b.1. Background}

The Malaysian communications industry through the CMA 1998 regulates competition and the competition provisions are contained in its Economic Regulation, which is in Part IV of the Act. The communications and multimedia industry is an industry that has witnessed rapid growth. Through the years we have seen the expansion of the industry from three distinct industries of tele- communications, broadcasting and IT which used to be regulated separately, to their merger into the communications and multimedia industry which is regulated under the Communications and Multimedia Act 1998 (CMA 1998).

The birth of the CMA 1998 is due to the advent of the information age, which adjoins with it the rapid technological advances that led to convergence. However, much of these were also contributed by the Multimedia Super Corridor (MSC) project, which aims to make Malaysia a regional communications hub. ${ }^{31}$

Preceding the CMA 1998, the broadcasting industry and the telecommunications industry was regulated by the Broadcasting Act 1988 and the Telecommunications Act 1950 respectively. Both these Acts do not have specific provisions for competition. However, the policy on competition in the telecommunications industry was stated in the National Telecommunications Policy (NTP) (1994-2020). ${ }^{32}$ Hence, policy statements in the NTP introduced competition in the Malaysian telecommunications industry.

The phrase 'competition' was stated in The National Telecommunications Policy (NTP) in various paragraphs. The NTP is clearly in line with the Government privatization process, which seeks to introduce competition into the industry in stages. ${ }^{33}$ The NTP will coordinate the establishment of a competitive environment both nationally and internationally ${ }^{34}$ by encouraging healthy participation of telecommunications companies in international market and encourage the partici-

25 Taylor, M, n. 56 at 81 where it was stated that most competition laws apply a blend of conduct-oriented (or per se) provision and resultoriented (or rule of reason) provisions. Conduct-oriented provisions are provisions that absolutely prohibits certain conducts without any consideration of the effect of those conduct on the market. Result-oriented or rule or reason provisions are provisions that require the assessment of the conduct to see its effect on the market. This kind of approaches is more flexible in the sense that conduct are not expressly prohibited and it gives greater flexibility and discretion to the regulation but it also creates uncertainty. However, this uncertainty may be reduced with guidance into the interpretation and application of the provision via case laws or administrative guidelines. The nature of the approaches is much influenced by the institutional framework regulating competition in each nation. Result-oriented is most preferred if the country has much experience in case law and expert in the area. Nevertheless, if the nation's regulation consist of mainly executive enforcement agencies, conduct-oriented is seen predominantly in the competition law. Another common character in competition law under the rule of reason approach involves the application of a three stage process: i. market definition; ii. the degree of market power; and iii. the assessment of the conduct in question.

26 For example, things that may be considered - government development policies, government companies, SMEs.

27 To prevent anti-competitive conduct or the abuse of dominant position.

28 Measures taken after the event e.g. fines.

29 Monitor changes in market structure, prevent firms from becoming concentrated.

30 List of anti-competitive conducts deemed illegal, rule of reason.

31 New Straits Times, Tuesday, July 21, "Communications and Multimedia Bill Tabled", 1998.

32 Ministry of Energy, Telecommunications and Posts, 1994.

33 Paragraph 7, The National Telecommunications Policy (NTP) (1994 - 2020), Ministry of Energy, Telecommunications and Posts, 1994.

34 Paragraph 11 \& 12, The National Telecommunications Policy (NTP) (1994 - 2020), Ministry of Energy, Telecommunications and Posts, 1994. 
pation of bumiputra entrepreneurs in the sector. ${ }^{35}$ In its strategies, it is stated that the NTP's main approach is to encourage (as opposed to preserve) competition. ${ }^{36}$ Nevertheless, while the whole NTP encourages competition it does not suggest for the development of a separate system for competition. The NTP do not provide a detailed rule for regulating competition in the industry similar to the one under the Communications and Multimedia Act 1998. Under the NTP, the government is also empowered to determine the number of competitors that are economically viable for certain telecommunications systems/services. However, having said this the NTP also stated that it would provide a healthy environment and equal opportunities to all competitors in the telecommunications industry. These two statements conflict with each other. Similar conflicting statements are found in the new regime under the CMA 1998 with reference to the limitation on the number of players. In April of 1999 the Communications and Multimedia Act 1998 (CMA 1998) came into force. This Act introduces a sector-specific competition regulation into the industry under Part IV (Economic Regulation) of the CMA 1998. There is however, no reference to the competition policy statements of NTP in the CMA 1998. Nevertheless, the Economic Regulation under the CMA 1998 applies a broader definition of economic regulation, which includes competition regulation. The Economic Regulation under the CMA 1998 consists of entry-exit condition (i.e. licensing), general competition practices provisions and access to services. ${ }^{37}$

\section{b.2. Policy And Objectives Behind the CMA 1998}

The CMA 1998 is an Act to provide for and regulate the converging communications and multimedia industries. In relation to competition law, the Act seeks to provide a generic set of regulatory provisions based on generic definitions of markets and service activities and services. ${ }^{38}$ The objects of the Act is stated in section 3(1) where it states:

(a) to promote national policy objectives for the communications and multimedia industry;

(b) to establish a licensing and regulatory framework in support of national policy objectives for the communications and multimedia industry;

(c) to establish the powers and functions for the Malaysian Communications and Multimedia Commission; and

(d) to establish powers and procedures for the administration of the Act.

Section 3(2) states the national policy objectives stated in paragraph (a) of section 3(1). Section 3(2) of the CMA 1998 provides, The national policy objectives for the communications and multimedia industry are-

(a) to establish Malaysia as a major global centre and hub for communications and multimedia information and content services;

(b) to promote a civil society where information-based services will provide the basis of continuing enhancements to quality of work and life;

(c) to grow and nurture local information resources and cultural representation that facilitates the national identity and global diversity;

(d) to regulate for the long-term benefit of the end user;

(e) to promote a high level of consumer confidence in service delivery from the industry;

(f) to ensure an equitable provision of affordable services over ubiquitous national infrastructure;

(g) to create a robust applications environment for end users;

(h) to facilitate the efficient allocation of resources such as skilled labour, capital, knowledge and national assets;

(i) to promote the development of capabilities and skills within Malaysia's convergence industries; and

\footnotetext{
35 Paragraph 14.2.12, The National Telecommunications Policy (NTP) (1994 - 2020), Ministry of Energy, Telecommunications and Posts, 1994.

36 Paragraph 15.3, The National Telecommunications Policy (NTP) (1994 - 2020), Ministry of Energy, Telecommunications and Posts, 1994.

37 Which is both the preservation of market concentration that might threaten the competitive functioning of markets (general competition law) and the restriction to firms' decisions over prices, quantity and entry-condition through licensing and access to services. This broader approach is similar to the approach taken by the OECD.

38 Paragraph 6, Explanatory statement to the CMA Bill.
} 
(j) to ensure information security and network reliability and integrity.

\section{b.3. Economic Regulation}

Part IV (Economic Regulation) of the Act establishes the framework for an economic regulation. The objectives of the economic regulation are to promote consumer markets, which offer choice, quality and affordability, any-to-any connectivity, competition in markets and investments and innovation in the communications and multimedia sector. ${ }^{39}$ Economic Regulation under the CMA 1998 is the Part that regulates competition in the communications industry. In the Economic Regulation, control of market entry is done through licensing, promotion of fair and sustainable competition in the industry is maintained by specific sector regulations and accessibility of connection at every level of the industry is warranted by the provision on access to services.

The Economic Regulation consists of three chapters. Licensing provisions in Chapter 1 of the Economic Regulation ensures the ability on the part of the regulators to impose various conditions on market participation. Chapter 2 of the Economic Regulation, which deals with general competition practices and its purposes are:

(i) To provide protection for smaller providers in the absence of a general competitive policy or trade practices regulatory regime;

(ii) To provide a context for, and certainty about, the manner in which the general powers and procedures under the Act should be administered. This reinforces the regulatory intent of the national policy for the development of the communications and multimedia industry; and

(iii) To establish a framework and clear powers for the Commission to ensure that anticompetitive practices do not undermine the national policy. ${ }^{40}$
Chapter 3 of the Economic Regulation deals with access to services. It aims to establish a regime that ensures all network facilities providers, network service providers and applications service providers can gain access to the necessary facilities and services on reasonable terms and conditions. ${ }^{41}$

\section{Conclusion}

Malaysia used to be more familiar with economic regulation which dealt mostly with conduct oriented approaches like regulation on market entry and price. Malaysia's own Competition Act 2010 that applies to all sectors of the industries, which not only covers conduct oriented approaches but also structure and market conduct activities will only come into force in 2012. With the enactment of the Competition Act 2010, Malaysia's industries will have to compete to survive in the market. Liberalization and opening up the markets means there will be more product or services with cheaper prices. The Competition Act 2010 will regulate anti-competitive behaviors and hopefully dilute monopolies in the industries with the existence of a competitive market. Nevertheless, the CMA 1998 would be exempted from the application of the Competition Act 2010. The rationale for this exemption s due to the fact that the communications and multimedia industry has formulated their competition regulation much earlier. Another reason for such exemption could also be attributed to the fact that in most countries the assimilation of competition regulation in the communications industry into the general competition law needs to be done in phases.

The importance of competition law is seen from the various initiatives made by international bodies. Model laws, agreements and directives to regulate competition have been made. In relation to the communications industry, general laws or specific rules may be applied.

\section{REFERENCES}

\section{Book}

Khairiah Salwa Mokhtar, 2008, Privatisation Malaysia Airlines, Penerbit UKM.
Lee, C, 2002, "The Institutional Policy Framework For Regulation And Competition

\footnotetext{
39 Paragraph 69, Explanatory Statement to the Bill. 
In Malaysia", Centre on Regulation and Competition Working Paper Series, Institute for Development Policy and Management, University of Manchester.

Vascusi, W, Kip, Vernon, J.M, Joseph, E, Harrington, Jr., 2000, Economies of Regulation and Antitrust, Third Edition, Cambridge, MIT Press.

\section{Journal}

Baumol, W, 1977, "The Proper cost Tests or Natural Monopoly in a Multiproduct Industry", American Economic Review 67.
New Straits Times, Tuesday, July 21, 1998, Communications and Multimedia Bill Tabled.

Shila Dorai Raj, 2008, "The Need to Have a Competition Law in Malaysia" Half-Day Seminar on Competition Law \& Policy: Future \& Prospect in Malaysia, Faculty of Law, IIUM.

\section{Regulation}

Competition Act 2010.

Securities Commission Act 1993

The Communications and Multimedia Act 1998. 